\title{
Fire-retardant and fire-barrier poly(vinyl acetate) composites for sealant application
}

\author{
Z. Al-Hassany, A. Genovese, R. A. Shanks* \\ CRC for Polymers, School of Applied Sciences, RMIT University, GPO Box 2476V Melbourne 3001, Australia
}

Received 4 May 2009; accepted in revised form 10 November 2009

\begin{abstract}
Fire-retardant ceramifying poly(vinyl acetate) (PVAc) sealants have been prepared. The degradation of PVA was integrated with the action of the fire retardants to reduce flammable gases, produce carbonaceous char and convert the fillers into a self-supporting ceramic barrier. PVA is readily degraded by elimination of acetic acid, yielding a char that provides a transitory phase as the filler particles fuse into a ceramic mass. Acetic acid is eliminated at similar temperature to the release of water from magnesium hydroxide fire-retardant, thereby diluting flammable acetic acid. The residual oxide from the fire-retardant filler and structural filler are fused by a flux, zinc borate. The degradative and ceramifying processes were characterised using thermogravimetry, infrared spectroscopy, scanning electron microscopy and ceramic strength. Thermogravimetry of the composites was compared with additive mass loss curves calculated from the components. Deviations between the experimental and additive curves revealed interactions between the components in the composites. The modulus of the PVAc composites and the strength of their ceramic residues after combustion were determined.
\end{abstract}

Keywords: thermal degradation, poly(vinyl acetate), fire-retardant, zinc borate, clay

\section{Introduction}

There is considerable interest in the field of fireretardant polymer based materials as the demand for improved safety in domestic, public and industrial situations is required by fire-safety standards. The most successful fire-retardant compounds for poly(vinyl acetate) (PVAc) materials are those that react chemically with the substrate and act in the condensed phase. Compounds that form part of a composite ideally should exhibit multifunctional ability. Examples of such fire-retardants are magnesium hydroxide $\left(\mathrm{Mg}(\mathrm{OH})_{2}\right)$ and zinc borate $\left(2 \mathrm{ZnO} \cdot 3 \mathrm{~B}_{2} \mathrm{O}_{3} \cdot 3.5 \mathrm{H}_{2} \mathrm{O}\right)$. Fire retardants change the decomposition path of polymers during heating so as to reduce the concentration of combustible volatiles and promote char formation. The char may be intumescent, offering heat and fire resistance until it reaches a critical temperature above which it burns [1-3].

*Corresponding author, e-mail: robert.shanks@rmit.edu.au (C) BME-PT
The use of intumescent char systems is important for building infrastructure protection where emulsion polymers have been applied in coatings, paints and sealants. On heat exposure of these type of materials, activation and formation of an intumescent char occurs that provides an insulating barrier between the fire and the underlying substrate. An intumescent char normally results from a significant volume increase or thickness of a foam-like layer. Fire protection by coatings that proceed via intumescence increase the path for heat transfer and increase the thermal gradient from the charred surface to the substrate polymer [4]. A structure requires stabilisation for a char with structural integrity to be formed, and this is achieved by fusion or by promoting adherence of condensed layer components, such as formation of a ceramiclike phase. Various components are used to provide this function; a silicate mineral providing a struc- 
tural network, binders such as zinc borate that are capable of forming an amorphous phase on softening and a fluxing capability. Other components can be added to provide fire retardant functions and to participate in structure formation [5-15].

A series of kaolin and talc composites with varying filler content was investigated with particular attention to the formation of a fused char or ceramic. Talc and kaolin were used to enhance the stiffness and strength of the composite and ceramic materials. In addition to the component properties, the mechanical characteristics of these materials are influenced by the interfacial interactions that depend on the interface and the cohesive strengths. Thermal degradation of PVAc gives quantitative yields of acetic acid, produced by an elimination reaction leading to a polyalkene residue $[16,17]$. This process gives rise to the formation of an intumescent residue with conjugated $\mathrm{C}=\mathrm{C}$ bonds with cyclic and aromatic structures [18]. The double bonds produced by the elimination of acetic acid lead to an increase in the rate of adjacent thermal degradation. The degradation of PVAc occurs in two stages: the first stage starts at $350^{\circ} \mathrm{C}$, and the second stage at $400^{\circ} \mathrm{C}$. Simultaneously, the fire retardants undergo decomposition over similar temperature ranges although their presence enhances the PVAc thermal stability. The PVAc intumescent char maintained the structure while a ceramic-like residue formed. The importance in maintaining a structure throughout the polymer decomposition and ceramic formation was influenced by the filler system and amount that is shown by the scanning electron microscopy (SEM) observations.

The aim was to interpret the action of ceramic barrier forming components on PVAc composites and their interactions according to their thermal decomposition reactions and analytical temperaturestructural analyses. The changes in char structure of the pure polymer and the composite with temperature were identified with Fourier transform infrared (FTIR) spectroscopy. An objective was the formation of a fused ceramic char that provides cohesive strength to maintain structural integrity during and after a fire. The effect of mineral type (kaolin or talc) and filler amount on the structure formed was evaluated through thermal stability measurements by thermogravimetry (TGA) and strength of char formed at elevated temperature. Fire retardant sealant composites mechanism of action as fireretardants in conjunction with char forming components that form a structural ceramic to maintain seal integrity is discussed.

\section{Experimental}

\subsection{Materials}

PVAc was obtained from Nuplex Industries Pty Ltd (Australia) as an emulsion of 55\% homopolymer in water. The calcined kaolin (K) was obtained from Burgess Pigment Company, Sandersville, GA, USA. The talc (T)(T38A) was obtained from Unimin Ltd, Australia. Magnesium hydroxide (M)(Magnifin 10H) was obtained from Magnesiaprodukte $\mathrm{GmbH}$ and Company KG, Germany. Zinc borate (ZB)(Firebrake ZB) was obtained from US Borax.

\subsection{Composite preparation}

Three sets of composites were prepared with varying polymer weight fraction $(0.6,0.5,0.4$ and 0.3$)$. The filler mixtures have composition: Set A containing kaolin (0.57), $\mathrm{Mg}(\mathrm{OH})_{2}(0.24)$, zinc borate $(0.1)$ and glass frit (0.09), Set B containing mineral (either kaolin or talc) (0.57), $\mathrm{Mg}(\mathrm{OH})_{2}(0.34)$, glass frit (0.09) (without zinc borate), and Set $\mathrm{C}$ containing talc (0.57), $\mathrm{Mg}(\mathrm{OH})_{2}(0.24)$, zinc borate $(0.1)$ and glass frit (0.09). The filler mixture was preblended in dry form. Using the abbreviations defined in Materials, the code for each composite includes the name PVAc, followed by $\mathrm{K}$ or $\mathrm{T}$, and ZB or NZB (for no ZB) with the number after the component designating its weight fraction.

The filler mixture was pre-blended in dry form. The composites were prepared using an IKA-Werke stirrer Eurostar power control-viscosity model P4 with kneading stirrer blade operating at $\sim 290 \mathrm{rpm}$. The required amount of polymer was weighed and placed into a stainless steel mixing container. The corresponding filler was slowly added into the stirred emulsion for a minimum of 5 min to obtain a uniform mixture. The thick paste mixture was spread into a Teflon based mould $(3 \mathrm{~mm})$ and dried at room temperature overnight followed by further drying under vacuum at $60^{\circ} \mathrm{C}$ for $48 \mathrm{~h}$. 


\subsection{Thermogravimetry}

Thermal degradation studies of the polymer and composites were conducted on a Perkin-Elmer TGA7. The samples were heated in an inert atmosphere of nitrogen with flow rate of $10 \mathrm{ml} \cdot \mathrm{min}^{-1}$ over the temperature range of 30 to $850^{\circ} \mathrm{C}$ at $10^{\circ} \mathrm{C} \cdot \mathrm{min}^{-1}$. The sample mass was $\sim 10 \mathrm{mg}$ and the changes in mass detected by the microbalance were recorded as a function of temperature.

PVAc was heated from $30^{\circ} \mathrm{C}$ to preselected temperatures determined from a thermogram $(360,445$ and $500^{\circ} \mathrm{C}$ ) at the same heating rate. At the end of the heating treatment, the residue was rapidly cooled to ambient temperature and stored in a desiccator for FTIR analysis.

\subsection{Fourier transform infrared analysis}

A Perkin-Elmer model 2000 Fourier transform infrared (FTIR) spectrometer was used in diffuse reflectance infrared Fourier transform (DRIFT) mode for the polymer and polymer residues obtained at the various temperatures noted previously. The spectra were obtained at a resolution of $8 \mathrm{~cm}^{-1}$ over the range of $4000-400 \mathrm{~cm}^{-1}$ with 16 accumulated scans. The scans were obtained under a nitrogen purge.

\subsection{Thermomechanometry}

Dynamic force (force changing linearly with time) - thermomechanical (df-TM) analysis of the polymer composite and residues were performed in three-point bend mode using a Perkin-Elmer DMA7e. The flexural modulus of the polymer composites was determined. Each polymer composite was placed on the three point bend fixture and a dynamic force scan was applied from 25 to $8000 \mathrm{mN}$ at $150 \mathrm{mN} \cdot \mathrm{min}^{-1}$. The linear region was used for Young's modulus and modulus at $0.2 \%$ strain. Measurements were conducted at least in triplicate.

The breaking strength of the chars was measured, after subjecting the composite to, various temperatures in an electric muffle furnace using an Instron model 4465 universal test instrument. A three-point bend configuration was used with a maximum static load of $100 \mathrm{~N}$ and crosshead speed of $0.2 \mathrm{~mm} \cdot \mathrm{min}^{-1}$. The rectangular specimen length was $30 \mathrm{~mm}$ and the width was $13 \mathrm{~mm}$. Ultimate stress was selected when fracture occurred as indicated by a rapid reduction of the load. It was calculated using Equation (1) (for rectangular specimens):

$S=\frac{3 P L}{2 b d^{2}}$

where $S$ is the maximum stress; $P$, load; $L$, span; $b$, width of the specimen; and $d$, depth of the specimen.

\section{Results and discussion}

\subsection{Degradation of PVAc}

TGA mass and derivative curves for PVAc treated under $\mathrm{N}_{2}$ at heating rate of $10^{\circ} \mathrm{C} \cdot \mathrm{min}^{-1}$ are shown in Figure 1. The majority of mass loss took place at $354^{\circ} \mathrm{C}$ due to acetic acid elimination from the polymer side-chains. This was followed by a smaller mass loss from the breakdown of the polymer backbone at the higher temperature of $450^{\circ} \mathrm{C}$. These unsaturated sequences re-arrange and decompose to aromatic and aliphatic hydrocarbons as will be confirmed by FTIR. The first stage of degradation was almost exclusively elimination of side groups, and the second stage was due to the thermal degradation of the polyalkene structures produced by the elimination reaction $[16,17]$. A complex array of free radical reactions, rearrangements and chain scissions led to the decomposition of the main chain as observed by the second slower mass loss $\left(\sim 6 \% \cdot \mathrm{min}^{-1}\right)$ in the mass loss curve. The derivative curve shows the mass loss steps as peaks.

Figure 1 reveals a gradual mass loss below $200^{\circ} \mathrm{C}$ that is attributed to the presence of tightly bound

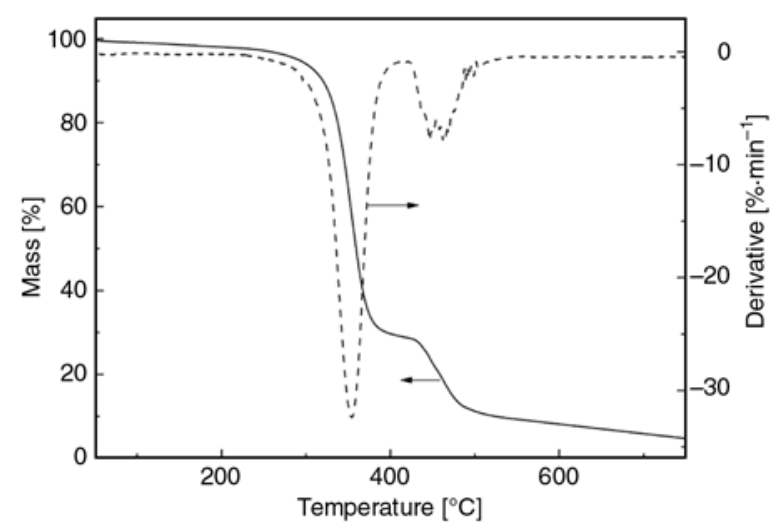

Figure 1. Thermogravimetric mass loss (-) and derivative (- - ) for the decomposition of PVAc under an inert atmosphere with heating rate of $10^{\circ} \mathrm{C} \cdot \mathrm{min}^{-1}$ 
water or traces of un-reacted monomer in the emulsion polymer that was not volatilised during the drying stage. The remaining mass loss at 420 $480^{\circ} \mathrm{C}$ is ascribed to the slower pyrolysis of the char that had formed through the main decomposition. A small residual amount (4\% for PVAc) still remained at $850^{\circ} \mathrm{C}$. The amount of acetic acid content of PVAc was determined theoretically by stoichiometry to be $72 \% \cdot \mathrm{wt}$ assuming quantitative loss of acetic acid. This means that the complete elimination of all acetate side-groups would lead to a char of $\sim 28 \%$ confirming that elimination of acetic acid was the predominant degradation process.

An indication of the degradation stages, temperature ranges and the nature of the reactions in each stage of PVAc were followed by FTIR. The FTIR spectra of PVAc residues are shown in Figure 2, at the temperatures indicated. The characteristic peaks of PVAc are summarised in the literature, and the current PVAc spectrum was compared with reference spectra $[4,16]$. PVAc shows asymmetric aliphatic $\mathrm{CH}_{3}$ and $\mathrm{CH}_{2}$ bands $\left(\mathrm{v}_{a}: 3000,2951 \mathrm{~cm}^{-1}\right.$, respectively) and their symmetric bands $\left(v_{s}: 2898\right.$, $2849 \mathrm{~cm}^{-1}$, respectively) are present $[4,16,17]$. The aliphatic $\mathrm{CH}_{3}$ has a band at 1422 and $1375 \mathrm{~cm}^{-1}$ corresponding to an asymmetric and a bending vibration. The ester carbonyl $(\mathrm{C}=\mathrm{O})$ of the func-

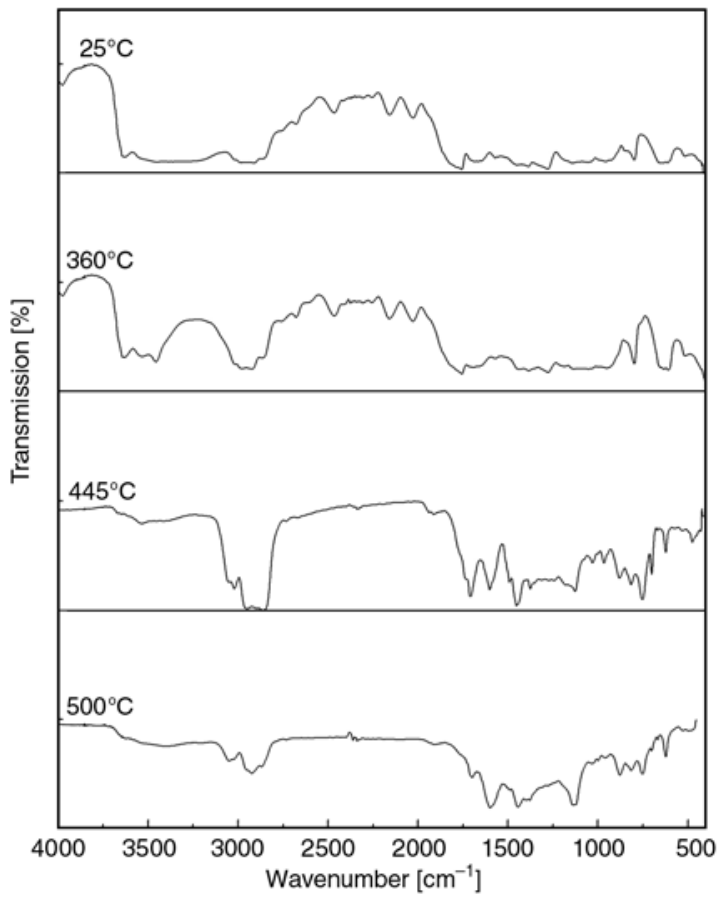

Figure 2. FTIR spectra of PVAc film from the emulsion at various stages of decomposition, obtained under an inert atmosphere; temperatures are indicated on the graph tional group symmetric band appeared at $1753 \mathrm{~cm}^{-1}$ and the $\mathrm{C}-\mathrm{O}-\mathrm{C}$ asymmetric and symmetric vibrations appeared at 1271 and $1115 \mathrm{~cm}^{-1}$, respectively [16].

The FTIR spectra of PVAc residues obtained at $360^{\circ} \mathrm{C}$ show peaks at $1753 \mathrm{~cm}^{-1}$ indicating that ester groups are still present, and the elimination of acetic acid at the end of the first stage is not fully complete. This effect can be due to the chain reaction of acetic acid elimination leaving some isolated ester groups between two double bonds in the polymeric structure of the residue; the 2921 and $1691 \mathrm{~cm}^{-1}$ bands characteristic of the internal unsaturation are fully developed. Simultaneously, there are signs of aromatisation bands that appeared at 1570,797 and $633 \mathrm{~cm}^{-1}$, and the 1382 band moves to $1453 \mathrm{~cm}^{-1}$. At $445^{\circ} \mathrm{C}$ the FTIR spectra of PVAc residues obtained were the same, as there was an increase in the degree of aromatisation in the residue and a decrease in the absorption of conjugated double bonds $\left(942 \mathrm{~cm}^{-1}\right)$ and increased absorptions at 2921 and $1437 \mathrm{~cm}^{-1}$. The presence of $760 \mathrm{~cm}^{-1}$ is attributed to the aromatic $\mathrm{C}-\mathrm{H}$ bending. A new $\mathrm{C}=\mathrm{O}$ band appeared at $1706 \mathrm{~cm}^{-1}$ at $500^{\circ} \mathrm{C}$. Hydroxyl and carbonyl groups are evident in the spectra obtained at high temperatures. This may arise from aromatisation of the aliphatic structures, as observed in the spectra of PVAc heated at $500^{\circ} \mathrm{C}$, which revealed a complete loss of aliphatic hydrocarbon groups $\left(2921 \mathrm{~cm}^{-1}\right)$ and a partial loss of carbonyl species. A high content of aromatic rings is fully developed as seen from the $\mathrm{C}-\mathrm{H}$ vibration of substituted polycondensed aromatic ring $\left(870,820,760\right.$ and $\left.700 \mathrm{~cm}^{-1}\right)$.

\subsection{Degradation of PVAc composites}

The thermal decomposition of filled PVAc composites containing kaolin or talc were investigated by incorporation of increasing amount of a particulate filler from 0.4 to $0.7 \mathrm{wt}$ fraction, although we refer to composites in regard to polymer content as detailed in Table 1. The thermogravimetric decomposition and corresponding derivative curves for the kaolin series (Set A) are displayed in Figure 3. Figure 3a shows the degradation of PVAcK0.6, containing $0.6 \mathrm{wt}$ fraction kaolin. The curve shows several stages in the decomposition profile with the onsets of each stage at $276,344,450$ and $573^{\circ} \mathrm{C}$. The derivative curve shows the stages more clearly 
Table 1. Thermogravimetry of PVAc and filled kaolin and talc composites series

\begin{tabular}{|c|c|c|c|c|c|c|}
\hline Composition & Mineral & $\begin{array}{c}\text { Composite ratio } \\
\text { PVAc : Filler }\end{array}$ & $\begin{array}{l}\mathbf{T}_{\text {onset }} \\
{\left[{ }^{\circ} \mathbf{C}\right]}\end{array}$ & $\begin{array}{c}\text { Derivative peak } \\
{\left[{ }^{\circ} \mathbf{C}\right]}\end{array}$ & $\begin{array}{c}\text { Mass remaining at } \\
\mathbf{8 5 0}^{\circ} \mathrm{C} \\
{[\%]} \\
\end{array}$ & $\begin{array}{c}\text { Rate of polymer } \\
\text { degradation } \\
{\left[\% \cdot \mathrm{min}^{-1}\right]}\end{array}$ \\
\hline PVAc & - & 100:0 & $\begin{array}{l}347 \\
488 \\
\end{array}$ & $\begin{array}{l}354(1) \\
450(2)\end{array}$ & 4 & -5.53 \\
\hline PVAcK0.6 & Kaolin & $60: 40$ & $\begin{array}{l}276 \\
344 \\
450 \\
573\end{array}$ & $\begin{array}{l}278(1) \\
389(2) \\
487(3) \\
643(4)\end{array}$ & 36 & $\begin{array}{r}-1.32 \\
-12.72 \\
-14.05 \\
-3.27\end{array}$ \\
\hline PVAcK0.5 & Kaolin & $50: 50$ & $\begin{array}{l}275 \\
322 \\
439 \\
\end{array}$ & $\begin{array}{l}286(1) \\
349(2) \\
472(3) \\
\end{array}$ & 51 & $\begin{array}{r}-0.79 \\
-12.01 \\
-2.45 \\
\end{array}$ \\
\hline PVAcK0.4 & Kaolin & $40: 60$ & $\begin{array}{l}323 \\
446\end{array}$ & $\begin{array}{l}342(1) \\
474(2)\end{array}$ & 59 & $\begin{array}{r}-15.11 \\
-3.01\end{array}$ \\
\hline PVAcK0.3 & Kaolin & $30: 70$ & $\begin{array}{l}332 \\
444\end{array}$ & $\begin{array}{l}354(1) \\
479(2)\end{array}$ & 70 & $\begin{array}{l}-9.31 \\
-1.75\end{array}$ \\
\hline PVAcT0.6 & Talc & $60: 40$ & $\begin{array}{l}284 \\
350 \\
460\end{array}$ & $\begin{array}{l}278(1) \\
375(2) \\
389(3) \\
492(4)\end{array}$ & 40 & $\begin{array}{r}-1.32 \\
-12.62 \\
-14.05 \\
-3.27\end{array}$ \\
\hline PVAcT0.5 & Talc & $50: 50$ & $\begin{array}{l}273 \\
345 \\
463\end{array}$ & $\begin{array}{l}276(1) \\
357(2) \\
382(3) \\
487(4)\end{array}$ & 48 & $\begin{array}{r}-1.01 \\
-9.77 \\
-13.85 \\
-2.65 \\
\end{array}$ \\
\hline PVAcT0.4 & Talc & $40: 60$ & $\begin{array}{l}255 \\
341 \\
390 \\
462\end{array}$ & $\begin{array}{l}269(1) \\
356(2) \\
413(3) \\
490(4)\end{array}$ & 55 & $\begin{array}{r}-1.05 \\
-10.04 \\
-8.04 \\
-1.81 \\
\end{array}$ \\
\hline PVAcT0.3 & Talc & $30: 70$ & $\begin{array}{l}268 \\
301 \\
390)\end{array}$ & $\begin{array}{l}258(1) \\
320(2) \\
352(3) \\
445(4)\end{array}$ & 68 & $\begin{array}{r}-0.56 \\
-11.87 \\
-8.62 \\
-1.54 \\
\end{array}$ \\
\hline
\end{tabular}
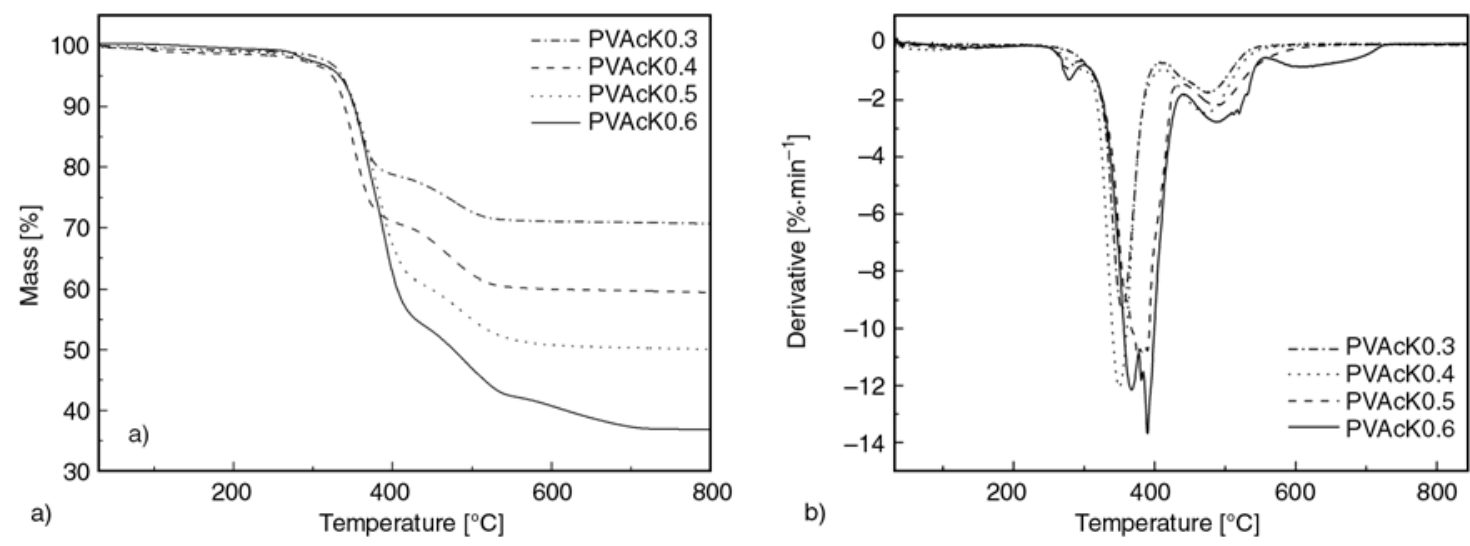

Figure 3. a) Thermogravimetric mass loss and b) derivative curves of fire retardant kaolin composite series under an inert atmosphere (Set A)

by the presence of the peaks as the mass loss rate changes. As previously observed, PVAc exhibited a small mass loss at temperature below $200^{\circ} \mathrm{C}$. In this range the fillers themselves lose negligible mass. A small mass loss at higher temperature was observed at $278^{\circ} \mathrm{C}$ as indicated by the small peak in the curve. The peak is attributed to the formation of water arising from $\mathrm{Mg}(\mathrm{OH})_{2}$ and the early stages of dehydration of zinc borate. Both these fire retarding fillers begin to decompose at similar temperatures $\left(>250^{\circ} \mathrm{C}\right)$. The maximum rate of mass loss occurs at $407^{\circ} \mathrm{C}\left(\sim 0.8 \% \cdot \mathrm{min}^{-1}\right)$ for $\mathrm{Mg}(\mathrm{OH})_{2}$ while zinc borate has two overlapping mass losses at 378 and $411^{\circ} \mathrm{C}\left(\sim 0.7 \% \cdot \mathrm{min}^{-1}\right)$ (Figure 4). Meanwhile, in the same temperature region, the deacetylation of PVAc occurs followed by structural disintegration 

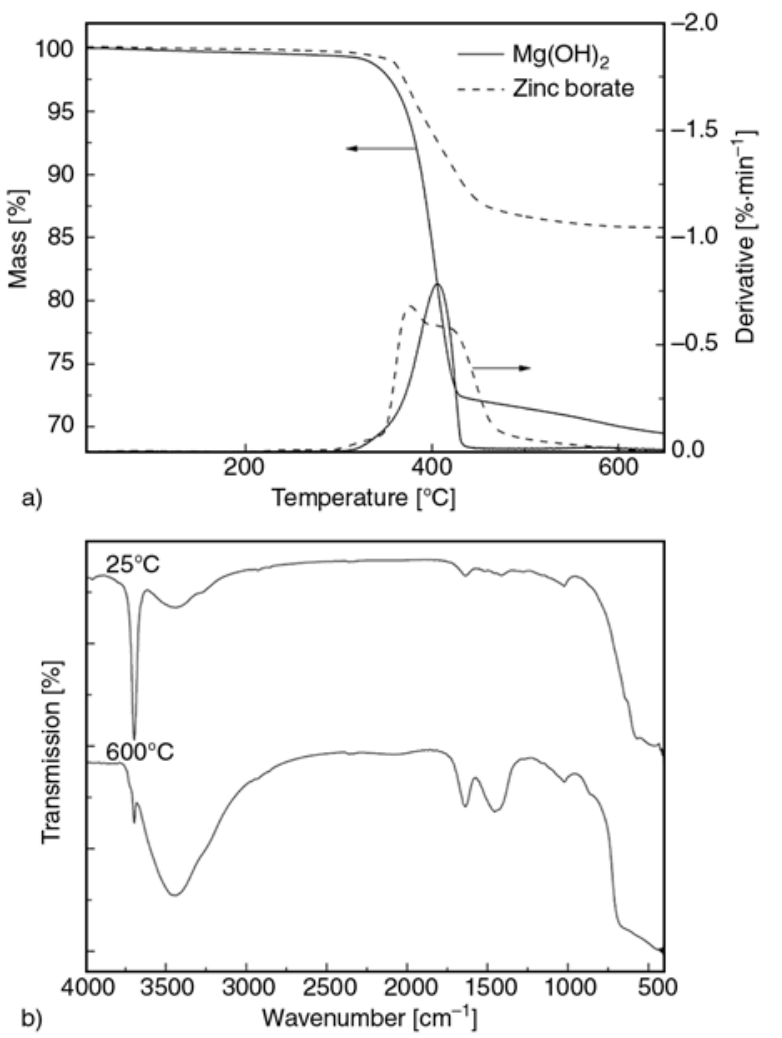

b)

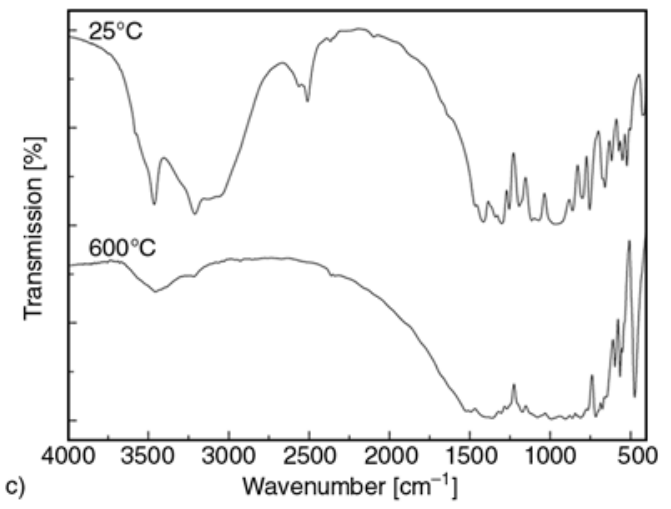

Figure 4. a) Thermogravimetry mass loss and derivative curves for fire retardants, $\mathrm{Mg}(\mathrm{OH})_{2}(-)$ and zinc borate (- - -) under an inert atmosphere, b) FTIR of $\mathrm{Mg}(\mathrm{OH})_{2}$ at $25^{\circ} \mathrm{C}$ and after degradation at $600^{\circ} \mathrm{C}, \mathrm{c}$ ) FTIR of zinc borate at $25^{\circ} \mathrm{C}$ and after degradation at $600^{\circ} \mathrm{C}$

of the polyolefin species, formation of aromatic species, isomerisation and formation of volatile compounds. The main decomposition temperature region encompassing these mass losses of various volatiles has resulted in a shift towards higher temperature. The degradation of PVAcK0.5 (Figure $3 \mathrm{~b}$ ) is similar to the degradation of PVAcK0.6 composite although it showed three stages of degradation, as the decomposition of fillers retards the polymer decomposition. These two composites decomposed at higher temperature compared with the original PVAc. This was due to the presence of fire retardant $\mathrm{Mg}(\mathrm{OH})_{2}$ and zinc borate in the PVAc composites which caused the deacetylation reaction to shift to higher temperature. The endothermic release of water from both fire retardants absorb heat while water formed and vaporised, cooling the substrate, particularly since $\mathrm{Mg}(\mathrm{OH})_{2}$ has a relatively high endothermic enthalpy of $1450 \mathrm{~J} \cdot \mathrm{g}^{-1}$ [19]. The water loss results in a decrease in the onset of the decomposition as listed in Table 1. Additionally, the shift in main polymer decomposition may also be due to the volatiles being absorbed on the filler surfaces, hence reducing mass loss until higher temperature is reached. This has been suggested to occur with $\mathrm{Mg}(\mathrm{OH})_{2}$ as it forms a high surface area inorganic $\mathrm{MgO}$ after decomposition [19]. The total amount of water eliminated on thermal dehydration of the $\mathrm{Mg}(\mathrm{OH})_{2}$ corresponded to $30.8 \% \cdot \mathrm{wt}$ and is consistent with theoretical value.

FTIR of $\mathrm{Mg}(\mathrm{OH})_{2}$ at ambient temperature and after degradation at $600^{\circ} \mathrm{C}$ is shown in Figure $4 \mathrm{~b}$. At ambient temperature the spectrum reveals the absorption $\mathrm{OH}$ bands that appeared at $3698 \mathrm{~cm}^{-1}$. The elimination of water and the formation of $\mathrm{MgO}$ is eventually seen in the spectrum of the $\mathrm{Mg}(\mathrm{OH})_{2}$ heated at $600^{\circ} \mathrm{C}$ with a broad band developed in the range of 3698 and $2750 \mathrm{~cm}^{-1}$, and appearance of new bands of 1650 and $1450 \mathrm{~cm}^{-1}$.

Studies which illustrated the effectiveness of $\mathrm{Mg}(\mathrm{OH})_{2}$ as a flame retardant in polymers have concluded that $\mathrm{Mg}(\mathrm{OH})_{2}$ is effective at reducing smoke emissions from burning polymers [20]. In addition to the endothermic decomposition, the fire retardant slows the rate of thermal degradation of the polymer by dilution of the fuel supply with water vapour present in the gaseous phase. These factors, and its high heat capacity, reduce the thermal energy available to degrade the polymer [21]. The $\mathrm{MgO}$ provides an increased insulation barrier for the polymer from the heat source through char formation [22].

The high filler content composites PVAcK0.4 and PVAcK0.3 (Figure 3c, 3d respectively) show two main stages of degradation with onset at $322 \pm 10^{\circ} \mathrm{C}$ and the maximum rate of mass loss at $349^{\circ} \mathrm{C}$. This indicates that the fire retardants enhance the thermal stability, as the material degrades more slowly at $439^{\circ} \mathrm{C}$ with a maximum mass loss at $472 \pm 5^{\circ} \mathrm{C}$. A 7 to $10 \%$ residue is formed at $500^{\circ} \mathrm{C}$ that is stable 
to $800^{\circ} \mathrm{C}$. The decomposition for high filler content, starts at comparatively lower temperature, but the material is more stable over a higher temperature range, i.e. up to $500^{\circ} \mathrm{C}$, for reasons explained earlier. Whereas high polymer content (PVAcK0.6 and PVAcK0.5), degradation starts at higher temperature and the material is stable at $800^{\circ} \mathrm{C}$. Decomposition products continue to degrade by random chain scission to form the final product that contains polyalkene residue, $\mathrm{MgO}$ and boron oxide with a lower molar mass.

According to Sivalingam and Madras [23], the PVAc is mildly affected by the metal oxide in this case $(\mathrm{MgO})$. The degradation of PVAc starts with the release of acetic acid and this can react with the metal oxide $(\mathrm{MgO})$ to form metal acetate. Therefore $\mathrm{MgO}$ may have induced the decrease in the decomposition temperature from the catalytic basic oxide surfaces. From $300-400^{\circ} \mathrm{C}$, the degradation of the polymer composites was high due to anticipated degradation of $\mathrm{Mg}(\mathrm{OH})_{2}$. In the $400-530^{\circ} \mathrm{C}$ temperature range the degradation of polymer composites was lower than the expected. This may be due to the reaction of the additives with the products of degradation of PVAc.

The action of zinc borate comes into account primarily for its fluxing and purpose of binding the inorganic fillers in the composite. Zinc borate is able to undergo dehydration, $\sim 11 \%$.wt of water in the temperature range of $290-450^{\circ} \mathrm{C}$, although the endothermic process is less effective than $\mathrm{Mg}(\mathrm{OH})_{2}$. A small proportion of zinc borate, in particular $2 \mathrm{ZnO} \cdot 3 \mathrm{~B}_{2} \mathrm{O}_{3} \cdot 3 \mathrm{H}_{2} \mathrm{O}$, acts as a synergistic agent in polyolefins as has been cited in literature [7, 24] and hence this is extended in PVAc-based formulations. The dehydration can be described by Equation (2) that has an amorphous structure with boric oxide beneficial for the purpose of improving the char properties:

$$
2 \mathrm{ZnO} \cdot 3 \mathrm{~B}_{2} \mathrm{O}_{3} \cdot 3 \mathrm{H}_{2} \mathrm{O} \rightarrow 2 \mathrm{ZnO} \cdot 3 \mathrm{~B}_{2} \mathrm{O}_{3}+3 \mathrm{H}_{2} \mathrm{O}
$$

FTIR of zinc borate at ambient temperature and after degradation at $600^{\circ} \mathrm{C}$ is shown in Figure $4 \mathrm{c}$. At ambient temperature zinc borate spectrum reveals absorption bands that appeared at 3490, 3250 and $2500 \mathrm{~cm}^{-1}$ respectively. These bands have disappeared after the calcination of zinc borate at $600^{\circ} \mathrm{C}$ due to the elimination of water and the formation of the new amorphous zinc borate which is eventually seen in the spectrum with a broad band that developed in the range of $\sim 3700$ and $2700 \mathrm{~cm}^{-1}$.

Figure 5a and 5b show the kaolin- $\mathrm{Mg}(\mathrm{OH})_{2}$ and talc- $\mathrm{Mg}(\mathrm{OH})_{2}$ filled PVAc with no zinc borate for the high and low polymer content. It can be observed that both the mineral- $\mathrm{Mg}(\mathrm{OH})_{2}$ composites show several degradation stages. The first stage is indicated by a small peak due to the formation of water arising from the beginning of $\operatorname{Mg}(\mathrm{OH})_{2}$ decomposition. The second stage shows that acetic acid elimination from PVAc started to occur, both overlapping with volatile formation simultaneously formed. The third stage is attributed to the structural degradation of the polyalkene backbone in the PVAc.

The TG curves of the PVAc composites revealed an interaction between zinc borate and $\mathrm{Mg}(\mathrm{OH})_{2}$ that took place during $\mathrm{Mg}(\mathrm{OH})_{2}$ decomposition. Zinc borate degrades well above $380^{\circ} \mathrm{C}$ (Figure 4a). The heat treatment of $\mathrm{Mg}(\mathrm{OH})_{2}$ and zinc borate in the polymer leads to the formation of boric oxide; this behaviour has been shown to occur with different zinc borates [25, 26]. Boric oxide is said to form an
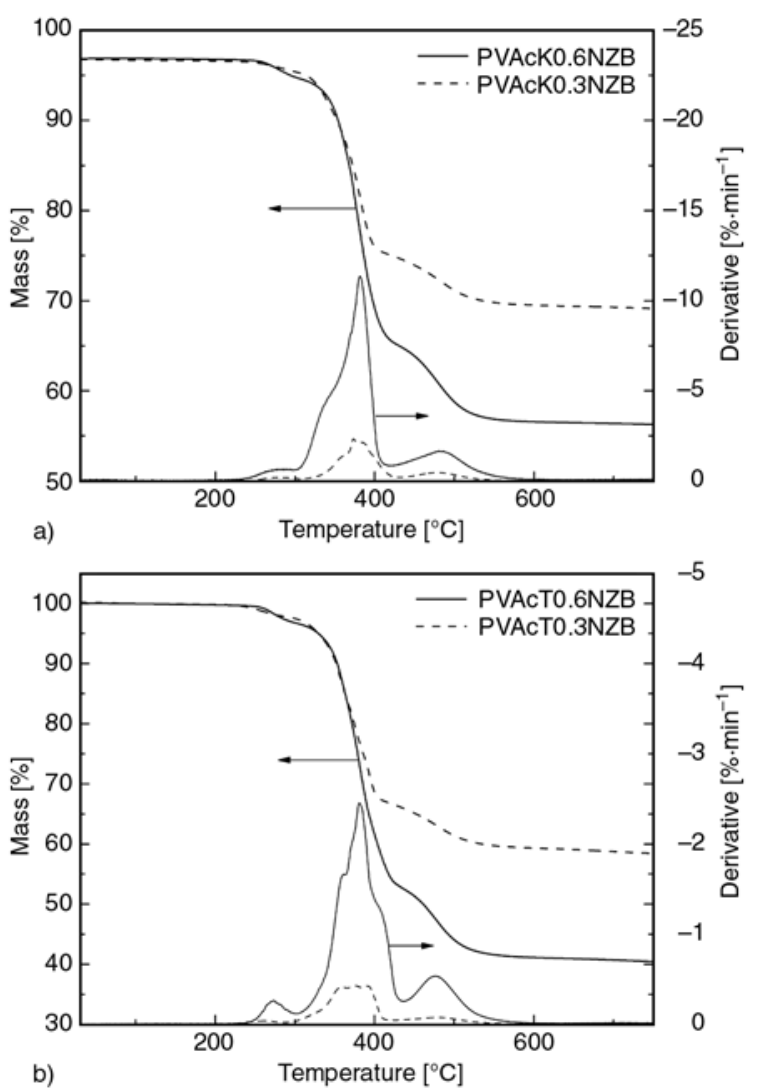

Figure 5. Thermogravimetric mass loss and derivative curves of fire retardant a) kaolin- $\mathrm{Mg}(\mathrm{OH})_{2}$ and b) talc- $\mathrm{Mg}(\mathrm{OH})_{2}$ composite series with no zinc borate (NZB) under an inert atmosphere (Set B) 
amorphous glassy layer as a low temperature-fluxing component. This enabled it to function by binding filler particles and inhibiting oxygen mass transfer to the polymer fuel system and retarding further oxidation of the char.

Composites containing $\mathrm{Mg}(\mathrm{OH})_{2}$ as fire retardant component with no zinc borate (NZB) (Set B) (Figure 5) were prepared for comparison with the zinc borate composite systems. Several decomposition stages still occurred due to water released from $\mathrm{Mg}(\mathrm{OH})_{2}$, the elimination of acetic acid and decomposition of polyalkene residue. The polymer decomposition rate for PVAcK0.6 was -12.72 and $-2.12 \% \cdot \mathrm{min}^{-1}$ with and without zinc borate, respectively, indicating that the presence of zinc borate was important in the composites as it acts as a synergistic agent when it is introduced with $\mathrm{Mg}(\mathrm{OH})_{2}$. The mechanism of action of $\mathrm{Mg}(\mathrm{OH})_{2}$ to form a protective $\mathrm{MgO}$-ceramic and zinc borate reinforces its efficiency by acting as a binder (formation of $\mathrm{B}_{2} \mathrm{O}_{3}-\mathrm{ZnO}$ glass). This MgO-ceramic residue combined with the degraded polymeric material leads to a protective surface layer during decomposition. The onset of each stage was at 264,358 and $455^{\circ} \mathrm{C}$ for PVAcK0.6NZB, 260, 354 and $459^{\circ} \mathrm{C}$ for PVAcT0.6NZB, 269, 327, 381 and $484^{\circ} \mathrm{C}$ for PVAcK0.3NZB, and 259, 357, 375, 394 and $479^{\circ} \mathrm{C}$ for PVAcT0.3NZB. This suggested that excluding zinc borate decreased the onset temperature in comparison with PVAcK0.6, PVAcT0.6, PVAcK0.3 and PVAcT0.3 that contain zinc borate.
Table 2 lists the stages showing that without zinc borate present in the composite the degradation stages start at lower temperature. Consequently this indicated that having $\mathrm{Mg}(\mathrm{OH})_{2}$ by itself in the composites lead to an early decomposition for all of the four composites because of the release of water from $\mathrm{Mg}(\mathrm{OH})_{2}$ effectively cooling the substrate through the endothermic reactions that act in relation to fire resistance. Eliminating zinc borate leads to the disappearance of the amorphous phase, since zinc borate effect is due to the softening and retaining/trapping volatiles.

The substitution of kaolin by talc (Set C) leads to significant changes in the thermal stability, where the mass loss onset occurred at lower temperatures and improved thermal stability of the polymer composite decomposition. The deacetylation of the PVAc was shifted toward higher temperatures. The platelet structure of talc (2:1 layer structure, octahedral sheet sandwiched by two tetrahedral sheets) is compared with the structure of kaolin (1:1 layer structure, tetrahedral and octahedral sheets). Talc, having a smaller particle size and better wettability by polymers, enabled better dispersion and hence barrier properties to be formed [18]. The TG mass loss and derivative profiles of PVAcT0.6, PVAcT0.5 PVAcT0.4 and PVAcT0.3 shown in Figure 6 revealed four stages of degradation, as emphasised by the derivative curves.

The first small peak at $\sim 270^{\circ} \mathrm{C}$ is attributed to the formation of water arising from $\mathrm{Mg}(\mathrm{OH})_{2}$ and zinc

Table 2. Thermogravimetry of filled kaolin and talc composites with no zinc borate (NZB)

\begin{tabular}{|c|c|c|c|c|c|c|}
\hline Composition & Mineral & $\begin{array}{l}\text { Composite ratio } \\
\text { PVAc : Filler }\end{array}$ & $\begin{array}{l}\mathbf{T}_{\text {onset }} \\
{\left[{ }^{\circ} \mathbf{C}\right]}\end{array}$ & $\begin{array}{c}\text { Derivative peak } \\
{\left[{ }^{\circ} \mathbf{C}\right]}\end{array}$ & $\begin{array}{c}\text { Mass remaining } \\
\text { at } 850^{\circ} \mathrm{C} \\
{[\%]}\end{array}$ & $\begin{array}{c}\text { Rate of polymer } \\
\text { degradation } \\
{\left[\% \cdot \mathrm{min}^{-1}\right]}\end{array}$ \\
\hline PVAcK0.6NZB & Kaolin & $60: 40$ & $\begin{array}{l}264(1) \\
358(2) \\
455(3)\end{array}$ & $\begin{array}{l}276(1) \\
374(2) \\
382(3) \\
479(4)\end{array}$ & 39 & $\begin{array}{l}-0.19 \\
-2.32 \\
-2.12 \\
-0.46\end{array}$ \\
\hline PVAcK0.3NZB & Kaolin & $30: 70$ & $\begin{array}{l}251(1) \\
353(2) \\
450(3)\end{array}$ & $\begin{array}{l}269(1) \\
327(2) \\
381(3) \\
484(4)\end{array}$ & 68 & $\begin{array}{r}-0.59 \\
-3.60 \\
-11.32 \\
-1.63\end{array}$ \\
\hline PVAcT0.6NZB & Talc & $60: 40$ & $\begin{array}{l}260(1) \\
354(2) \\
459(3)\end{array}$ & $\begin{array}{l}272(1) \\
359(2) \\
380(3) \\
408(4) \\
476(5)\end{array}$ & 40 & $\begin{array}{r}-1.44 \\
-9.29 \\
-13.73 \\
-6.87 \\
-2.99\end{array}$ \\
\hline PVAcT0.3NZB & Talc & $30: 70$ & $\begin{array}{l}249(1) \\
344(2) \\
451(3)\end{array}$ & $\begin{array}{l}259(1) \\
357(2) \\
375(3) \\
394(4) \\
479(5)\end{array}$ & 68 & $\begin{array}{l}-0.71 \\
-8.42 \\
-8.62 \\
-9.14 \\
-1.46\end{array}$ \\
\hline
\end{tabular}



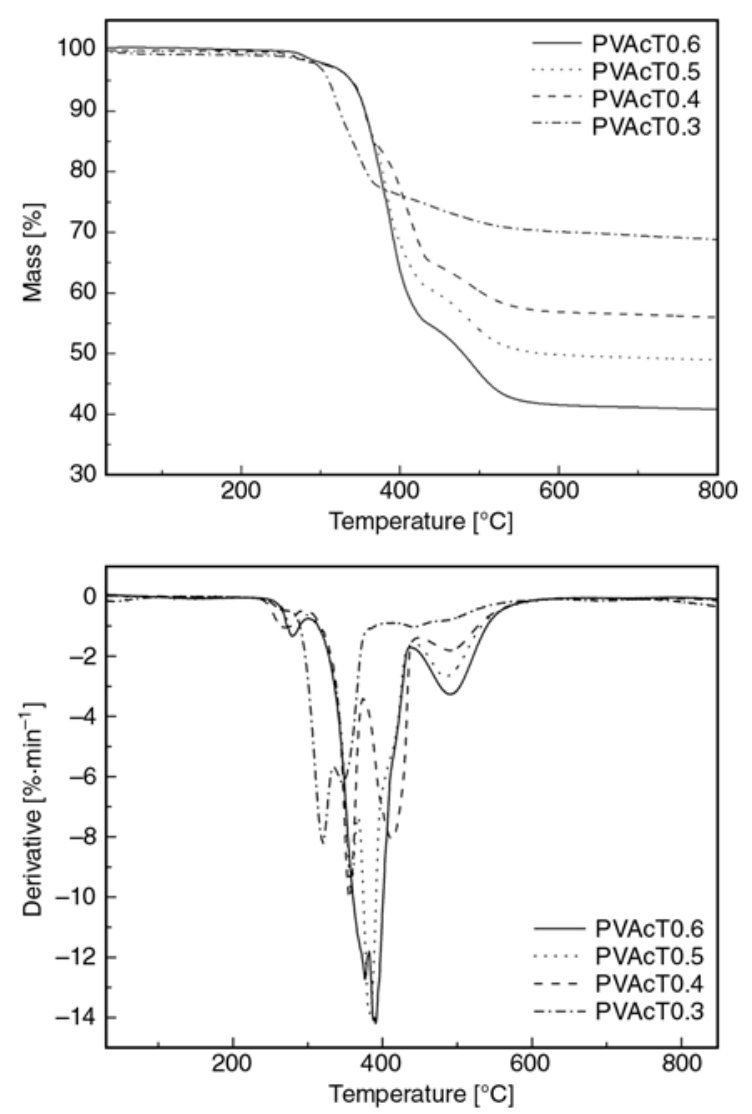

Figure 6. a) Thermogravimetric mass loss and b) derivative mass loss curves of fire retardant talc composite series under an inert atmosphere (Set C)

borate. The PVAcT0.4 and PVAcT0.3 (Figure 6c and 6d) show that this first peak is shifted to high temperature with the increased filler content, therefore a higher mass loss was observed than for PVAcT0.5 and PVAcT0.6 (Figure 6a and 6b) where the maximum mass loss occurred at $\sim 350^{\circ} \mathrm{C}$. The derivative curves for all talc composites show two overlapping peaks $\left(350\right.$ and $\left.390^{\circ} \mathrm{C}\right)$ due to the water loss from $\mathrm{Mg}(\mathrm{OH})_{2}$ and zinc borate in the same temperature region where the deacetylation of PVAc occurred. This was followed by a small mass loss due to the polymer backbone at $\sim 460^{\circ} \mathrm{C}$. The third peak that occurred at $390^{\circ} \mathrm{C}$ was more pronounced for the composites with high filler content, perhaps because the filler absorbed some degradation products that decomposed at higher temperature and were retarded by the filler. Table 1 showed that the rate of mass loss of the polymer component in the talc series decreased with increased filler content.

TG curves shown in Figure 6 indicate that talc has both a strong catalytic effect on deacetylation reaction (first mass loss) and a charring effect [18]. The talc seemed to promote the formation of a polymerfiller char that was comparatively more thermally stable. The derivative peak showed a small shift to higher temperatures (from $347^{\circ} \mathrm{C}$ for pure PVAc to $350^{\circ} \mathrm{C}$ for PVAcT0.6). PVAcT0.3 degradation started at lower temperature as shown in Figure 6 since it consisted of the highest talc content. According to Durin-Frances et al. [27], where they investigated the synergism of the additives, they focused on the binary and ternary composites, and found greater synergism between talc and zinc borate than between zinc borate and magnesium hydroxide, because talc tended to increase the thermal conductivity of the polymer that was caused by the lamellar particles of talc. The kaolin itself was calcined with $<1 \%$ mass loss present since organic matter and water would have been removed in the treatment, therefore the calcination process (dehydroxylation) was affected by the catalytic activity of kaolin compared with talc.

Theoretical curves were constructed from the individual component in their relative proportion to observe the influence of the fillers on the decomposition of the polymer. Figure 7 illustrates the enhanced thermal stability of the filled PVAc composites with the experimental and theoretical mass loss curves for the kaolin system. The effect on the PVAc degradation of adding the filler, in comparison with the calculated weight loss curves for respective amounts of each individual component, assumed that they were not influenced by each other. The measured mass loss indicated otherwise, with composites containing a high relative proportion of $\mathrm{Mg}(\mathrm{OH})_{2}$ and zinc borate filler (PVAcK0.3 (a and $a^{\prime}$ ) and PVAcK0.4 (b and $\left.b^{\prime}\right)$ ) exhibiting

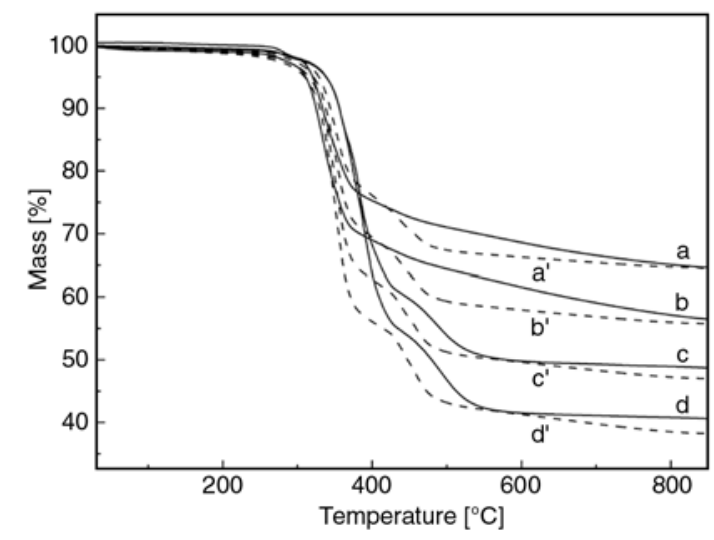

Figure 7. Thermogravimetric mass loss of fire retardant kaolin composite a) PVAcK0.3, b) PVAcK0.4, c) PVAcK0.5 and d) PVAcK0.6, measured and (a', b', c' and d') theoretically calculated 
decomposition at similar lower temperatures for the first mass loss stage. As temperature increased to about $400^{\circ} \mathrm{C}$, the mass loss rate measured was more gradual than that calculated.

Composites containing a lower amount of filler (PVAcK0.5 and PVAcK0.6) showed a higher temperature mass loss compared with the theoretical curve, indicating that a degree of mutual interactions existed between the phases present. The stages of decomposition for the acetic acid formation and pyrolysis of the polyalkene was more pronounced as the behaviour of the polymer degradation was the dominant process. These results show that although $\operatorname{Mg}(\mathrm{OH})_{2}$ and zinc borate filler decreased the initial thermal stability of the composite, the rate of degradation of PVAc can be reduced through the various mechanisms described above.

\subsection{FTIR analysis of PVAc kaolin composites series}

The FTIR spectra of PVAcK0.6 degraded under nitrogen in the TGA furnace at increasing heat treatment temperatures $(25,325,377,427,447$ and $500^{\circ} \mathrm{C}$ ) throughout the decomposition are shown in Figure 8 . This composition was selected as it provides a high temperature residue with a low decrease in the onset temperature of degradation. The FTIR spectrum of the original composite at ambient temperature showed typical absorption bands that were due to the polymer and fillers. FTIR peaks were observed for $\mathrm{Mg}(\mathrm{OH})_{2}$, while other peaks were due to zinc borate and kaolin (refer Figure 3b). The $\mathrm{Mg}(\mathrm{OH})_{2}$ peaks are at 3696,

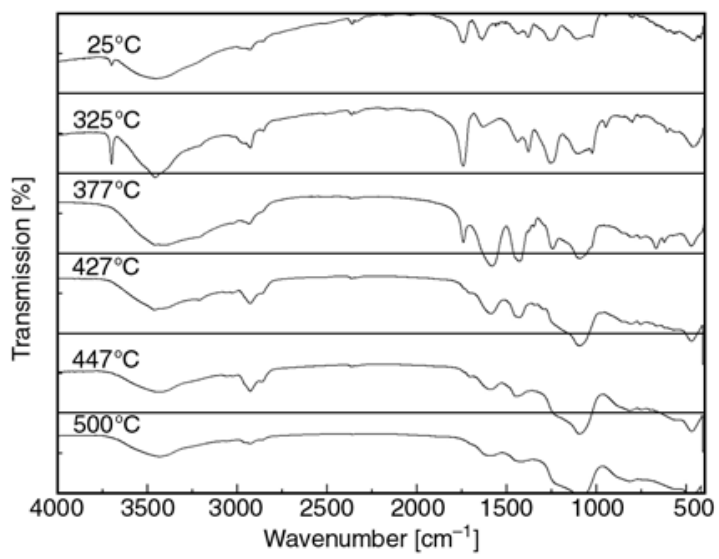

Figure 8. FTIR spectra of PVAcK0.6 residue degraded under an inert atmosphere at the various decomposition temperatures indicated on the graph
2923, 2363, 1638 and $1423 \mathrm{~cm}^{-1}$ respectively. The asymmetric aliphatic $\mathrm{CH}_{3}$ and $\mathrm{CH}_{2}$ bands from PVAc ( $v_{a}: 3000,2951 \mathrm{~cm}^{-1}$, respectively) were shifted to 3015 and $2934 \mathrm{~cm}^{-1}$ respectively due to overlap of kaolin and $\mathrm{Mg}(\mathrm{OH})_{2}$ bands. The aliphatic $\mathrm{CH}_{3}$ has bands at 1422 and $1375 \mathrm{~cm}^{-1}$ corresponding to asymmetric and symmetric bending vibrations that were shifted to 1435 and $1379 \mathrm{~cm}^{-1}$ respectively due to the presence of kaolin and zinc borate $[28,29]$. The ester carbonyl $(\mathrm{C}=\mathrm{O})$ of the functional group symmetric band that appeared at $1753 \mathrm{~cm}^{-1}$ was shifted to $1733 \mathrm{~cm}^{-1}$ due to $\mathrm{Mg}(\mathrm{OH})_{2}$ and kaolin and the $\mathrm{C}-\mathrm{O}-\mathrm{C}$ asymmetric and symmetric vibrations that appeared at 1271 and $1115 \mathrm{~cm}^{-1}$ were shifted to 1261 and $1107 \mathrm{~cm}^{-1}$ respectively [30].

At $325^{\circ} \mathrm{C}$, the spectrum shows the 3698,3455 and $2925 \mathrm{~cm}^{-1}$ bands that characterise the presence of $\mathrm{Mg}(\mathrm{OH})_{2}$, kaolin and zinc borate, a large band appeared at 1740 and $1630 \mathrm{~cm}^{-1}$ due to overlapping of kaolin and PVAc residue [31]. At $377^{\circ} \mathrm{C}$ the spectrum shows a broad band at $3415 \mathrm{~cm}^{-1}$ that demonstrates that the bands at 3698 and $3455 \mathrm{~cm}^{-1}$ were developed due to dehydration of zinc borate and the presence of $\mathrm{MgO}$ and aromatics (bands overlapping in the frequency range). Simultaneously, there are signs of aromatisation bands exhibited by the polymer that are detected at 1581,801 and $621 \mathrm{~cm}^{-1}$. Heat treatment at temperatures of 427,476 and $500^{\circ} \mathrm{C}$ showed a similar spectrum to that at the previous temperature of $377^{\circ} \mathrm{C}$. The spectrum shows the residue of the polymer and the fillers after the second stage of degradation that demonstrates that the bands are overlapped, and the main peaks present are 3430, 2926 (symmetric aliphatic $\mathrm{CH}_{3}$ and $\mathrm{CH}_{2}$ bands), $2360\left(\mathrm{CH}_{3}\right), 1592$ (aromatic ring), $1417\left(\mathrm{CH}_{2}\right.$ of the vinyl group), $1093\left(\mathrm{CH}_{2}\right.$ of the vinyl group) and $812 \mathrm{~cm}^{-1}$ (aromatic ring) respectively. Peaks were observed for the formation of $\mathrm{MgO}$ at 3500,1700 and $1500 \mathrm{~cm}^{-1}$.

\subsection{Mechanical properties}

The flexural properties of the PVAc composites were measured to observe changes with filler content. The modulus at $0.2 \%$ strain and Young's modulus are listed in Table 3. The flexural modulus for the composites was increased from 27 to $370 \mathrm{MPa}$ for the kaolin mineral based systems and from 7 to $470 \mathrm{MPa}$ for the talc mineral, as expected for 
Table 3. Modulus and residue strength of PVAc filled kaolin (Set A) and filled talc composites series (Set C)

\begin{tabular}{|l|c|c|c|c|}
\hline \multirow{2}{*}{ Formulations } & $\begin{array}{c}\text { Modulus at } \\
\text { 0.2\% strain } \\
\end{array}$ & $\begin{array}{c}\text { Young's } \\
\text { modulus } \\
{[\mathbf{M P a}]}\end{array}$ & \multicolumn{2}{|c|}{$\begin{array}{c}\text { Residue strength } \\
{[\mathbf{M P a}]}\end{array}$} \\
\cline { 4 - 5 } & $\mathbf{\mathbf { 4 0 0 } ^ { \circ } \mathbf { C }}$ & $\mathbf{1 0 5 0}^{\circ} \mathbf{C}$ \\
\hline PVAcK0.6 & 27 & 106 & 0.12 & 1.68 \\
\hline PVAcK0.5 & 179 & 1090 & 0.36 & 2.95 \\
\hline PVAcK0.4 & 249 & 1660 & 0.58 & 6.67 \\
\hline PVAcK0.3 & 370 & 1980 & 1.01 & 16.90 \\
\hline PVAcT0.6 & 7 & 3 & 0.07 & 0.15 \\
\hline PVAcT0.5 & 19 & 30 & 0.81 & 0.36 \\
\hline PVAcT0.4 & 180 & 277 & 0.98 & 1.33 \\
\hline PVAcT0.3 & 470 & 708 & 1.49 & 5.12 \\
\hline
\end{tabular}

increasing filler content. With low filler content, the composite displayed higher flexibility and this was reflected in the change in Young's modulus with higher filler content resulting in higher modulus of the composite. This is a typical trend for composites with the incorporation of rigid inorganic filler content [32].

Compositions PVAcK0.4 and PVAcK0.3 from the kaolin series, (modulus 249 and $370 \mathrm{MPa}$ respectively) and PVAcT0.4 and PVAcT0.3 from the talc series (modulus 180 and $470 \mathrm{MPa}$ respectively) that contained less polymer reveal higher Young's modulus indicating that these compositions were hard or stiff, whereas PVAcK0.6, PVAcK0.5 (modulus 27 and $179 \mathrm{MPa}$ respectively), PVAcT0.6 and PVAcT0.5 (modulus 7 and 19 MPa respectively) with high polymer content exhibited lower Young's modulus. These attributes had a consequence on the resulting residual strength after the heat treatments. An initial difference between the modulus of the kaolin and talc series was observed, with the kaolin series generally higher than the modulus of the talc series. This was due to the different particle structure and interaction between PVAc and talc [33, 34] than between kaolin and PVAc.

After burning the composites at 400 and $1050^{\circ} \mathrm{C}$, the phases underwent structural transformations. At $400^{\circ} \mathrm{C}$ the fire retardants had changed forms, with zinc borate contributing to formation of a flux that acted by binding of the other fillers present in the system, while a residual oxide was retained in the condensed phase from $\operatorname{Mg}(\mathrm{OH})_{2}$. The strength of the PVAc composites after burning was caused by an increase in a ceramic-like residue for both kaolin and talc composites that increased with increasing filler content, however the cohesion of the residue was relatively weak. The residue strength increased with increasing temperature as higher temperature changes in the condensed phase involved with the filler systems were activated. At $400^{\circ} \mathrm{C}$ the residue strength of the kaolin composites $(0.12,0.36,0.58$, and 1.01 respectively) was lower than that at $1050^{\circ} \mathrm{C}(1.68,2.95,6.67$ and 16.9 with increasing filler content). A similar trend was observed for the talc composites as listed in Table 3 . At $400^{\circ} \mathrm{C}$ the strength was low $(0.07,0.81,0.98$ and 1.49 respectively) but at $1050^{\circ} \mathrm{C}$ the strength was increased $(0.15,0.36,1.33$ and 5.12 respectively). The talc residues were stronger than those obtained with kaolin.

The increase in the strength for kaolin filled PVAc composites was mainly due to shrinkage of the material after burning that led to improved fusion and increased polymer-filler interaction. Stronger interaction enabled more stress to be transferred from the polymer to the fillers during loading. In addition, studies revealed that the specific surface area was one of the more important characteristics of the filler, determining the amount of the surface contact between the polymer and the filler [22, 35]. Fillers with high surface area contribute to more surface contact between the filler and the polymer, increasing the mechanical properties of the composites. Fillers with fine or small particles have higher surface area than fillers with larger particle size. However the finer the particles, the greater was their tendency to agglomerate and this can cause an adverse effect on the mechanical properties as shown in the SEM (Figure 9). Figure 9a and $9 \mathrm{~b}$ illustrate the SEM of PVAcK0.6 composite pyrolysed at $400^{\circ} \mathrm{C}$. Large voids are observed between the particles due to the degradation of the polymer and fusion was observed to form a ceramic-like structure that is shown in Figure $9 b$ (higher magnification of Figure 9a). Figure 9a reveals the continuous sheet structure of kaolin that produced thin particles, which are often found in nature as overlapping sheets. These sheets are bound via hydrogen bonding of the octahedrallayer hydroxyl face of one flake to the tetrahedrallayer oxygen face of an adjacent sheet.

At higher temperature $\left(1050^{\circ} \mathrm{C}\right)$ Figure $9 \mathrm{c}$ and $9 \mathrm{~d}$ show better fusion and reveal a higher stacking density of the fillers with a smaller distance between the particles. The talc composite PVAcT0.6 pyrolysed at $400^{\circ} \mathrm{C}$ is shown in Figure 9e and 9f. Many microvoids are present, compared with the kaolin 


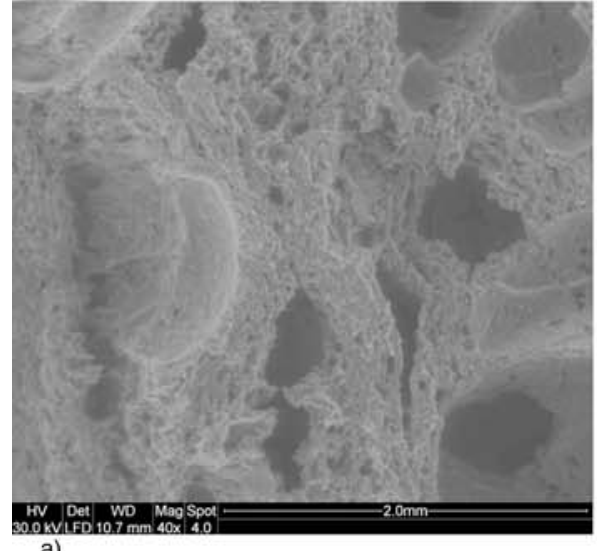

a)

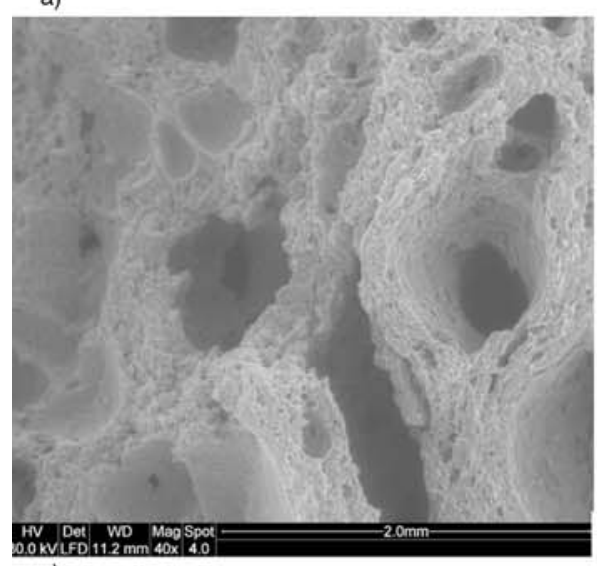

c)

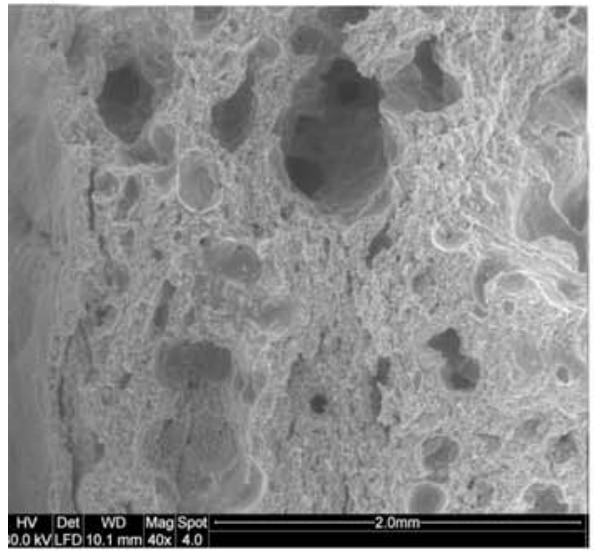

e)

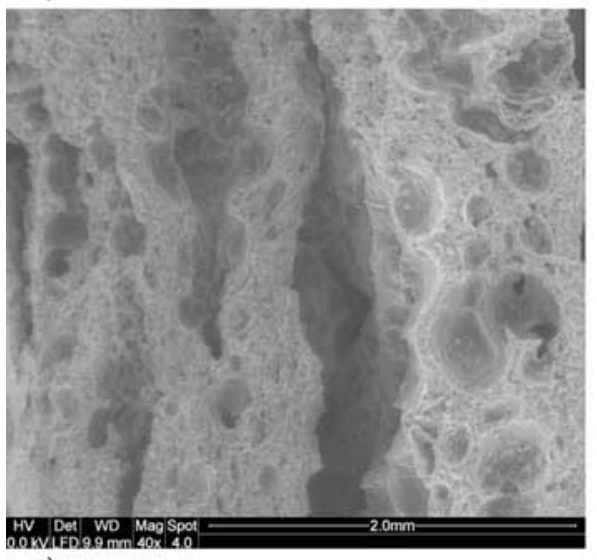

g)

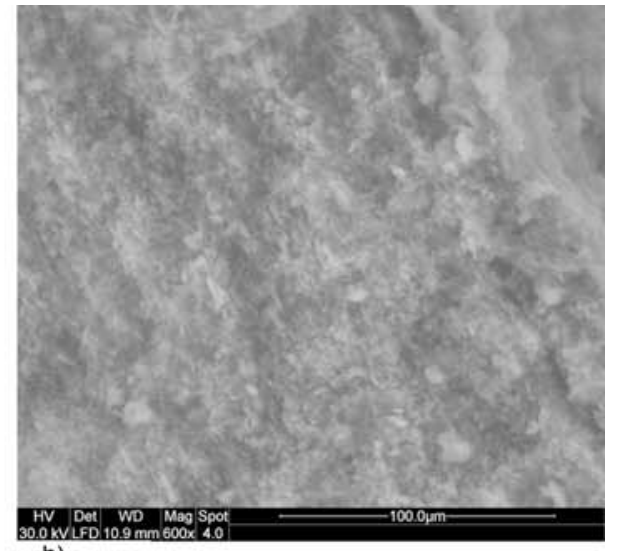

b)

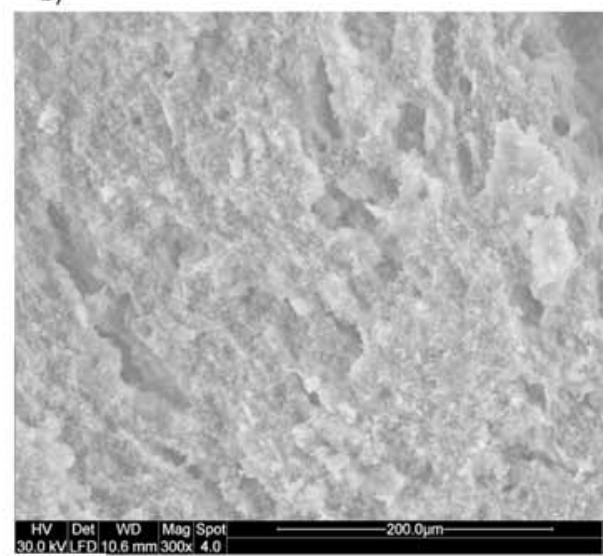

d)

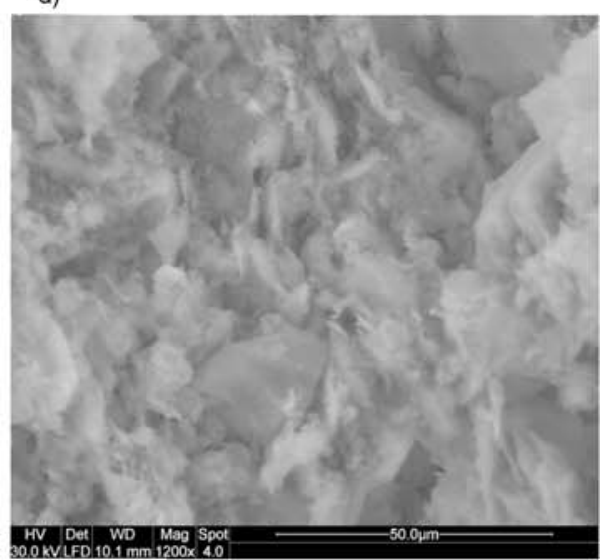

f)

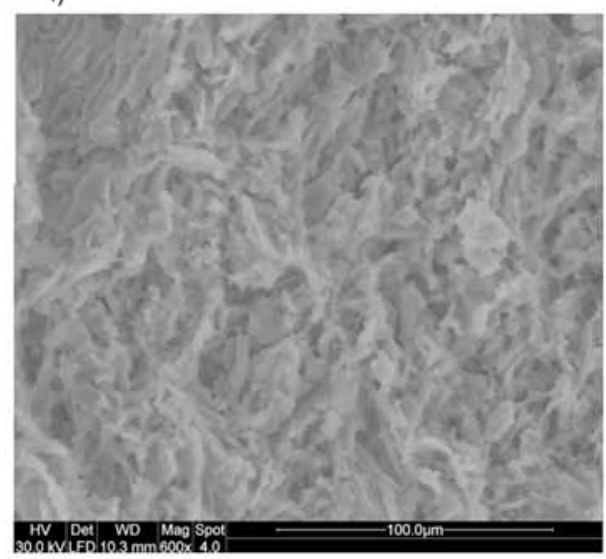

h)

Figure 9. SEM observation of PVAcK0.6 furnaced at $400^{\circ} \mathrm{C}$ (a and b), at $1050^{\circ} \mathrm{C}$ (c and d), and PVAcT0.6 burned at $400^{\circ} \mathrm{C}$ (e and $\left.\mathrm{f}\right)$ and at $1050^{\circ} \mathrm{C}(\mathrm{g}$ and $\mathrm{h})$ 
composite, due to the platy nature of talc. As mentioned, talc can be better wetted by polymer. The good interaction between polymer and talc enabled improved distribution of polymer, therefore leading to many more microvoids being formed as polymer was volatilised. Figure $9 \mathrm{~g}$ and $9 \mathrm{~h}$ show the PVAcT0.6 furnaced at $1050^{\circ} \mathrm{C}$ revealing comparatively better fusion however more cracks were present than at $400^{\circ} \mathrm{C}$. Figure $9 \mathrm{~h}$ shows the large particle size of talc, therefore the strength of this material was less than the material that contained kaolin. Formation of a ceramic residue after degradation and volatilisation of the polymer has found application in fire barrier sealant composites that prevents fire spread though gaps in building components [36]

\section{Conclusions}

Poly(vinyl acetate) composites produced with kaolin or talc as structural fillers, and with fire retardant magnesium hydroxide and zinc borate flux, formed a ceramic char after thermal degradation. The ceramic char had similar shape and size to the original composite and had sufficient strength to provide a barrier to spread of fire. Poly(vinyl acetate) readily decomposes with release of acetic acid, however it forms a polyalkene residue that further degrades with formation of aromatic structures. Magnesium hydroxide eliminated water over the same temperature range as acetic acid was formed, thus diluting the flammable acetic acid. Individual degradation steps became less pronounced as the filler content increased due to restricted emission of volatiles through the tortuous filler path. The organic polyalkene char maintained integrity of the inorganic components over the temperature range where the zinc borate flux formed a ceramic with the talc or kaolin, and magnesium oxide formed. Talc was chosen for its platelet particles that strengthened the ceramic, though the smaller kaolin particles provided a stronger ceramic at similar concentration. Talc provided higher thermal stability to the composites due to its platelet structure forming a better barrier to volatiles.

\section{Acknowledgements}

Zynab Al-Hassany acknowledges the award of a scholarship from the Co-operative Research Centre for Polymers.

\section{References}

[1] Camino G., Maffezzoli A., Braglia M., De Lazzaro M., Zammarano M.: Effect of hydroxides and hydroxycarbonate structure on fire retardant effectiveness and mechanical properties in ethylene-vinyl acetate copolymer. Polymer Degradation and Stability, 74, 457-464 (2001). DOI: $10.1016 / \mathrm{S} 0141-3910(01) 00167-7$

[2] Marosi G. J.: Fire retardancy of polymers: Challenges and new concepts. Express Polymer Letters, 1, 545 (2007). DOI: $10.3144 /$ expresspolymlett.2007.77

[3] Costa L., Avataneo M., Bracco P., Brunella V.: Char formation in polyvinyl polymers I. Polyvinyl acetate. Polymer Degradation and Stability, 77, 503-510 (2002).

DOI: $10.1016 / \mathrm{S} 0141-3910(02) 00108-8$

[4] Fu M., Qu B.: Synergistic flame retardant mechanism of fumed silica in ethylene-vinyl acetate/magnesium hydroxide blends. Polymer Degradation Stability, 85, 633-639 (2004).

DOI: 10.1016/j.polymdegradstab.2004.03.002

[5] Touré B., Lopez Cuesta J-M., Longerey M., Crespy A.: Incorporation of natural flame retardant fillers in an ethylene-propylene copolymer, in combination with a halogen-antimony system. Polymer Degradation and Stability, 54, 345-352 (1996). DOI: 10.1016/S0141-3910(96)00061-4

[6] Dvir H., Gottlieb M., Daren S., Tartakovsky E.: Optimization of a flame-retarded polypropylene composite. Composites Science and Technology, 63, 18651875 (2003).

DOI: $10.1016 / \mathrm{S} 0266-3538(03) 00170-2$

[7] Gibert J. P., Lopez Cuesta J-M., Bergeret A., Crespy A.: Study of the degradation of fire-retarded PP/PE copolymers using DTA/TGA coupled with FTIR. Polymer Degradation and Stability, 67, 437-447 (2000).

DOI: 10.1016/S0141-3910(99)00142-1

[8] Varma I. K., Sadhir R. K.: Thermal degradation of poly(vinyl acetate) in solution. Angewandte Makromolekulare Chemie, 46, 11-21 (1975). DOI: 10.1002/apmc.1975.050460102

[9] Zhang Z., Zhang J., Wang Y.: Modeling study on the combustion of intumescent fire-retardant polypropylene. Express Polymer Letters, 1, 157-165 (2007). DOI: $10.3144 /$ expresspolymlett.2007.25 
[10] Marosi G., Márton A., Anna P., Bertalan G., Marosfói B., Szép A.: Ceramic precursor in flame retardant systems. Polymer Degradation and Stability, 77, 259-265 (2002).

DOI: $10.1016 / \mathrm{S} 0141-3910(02) 00057-5$

[11] Shen K. K.: Zinc borate as a flame retardant in halogen-free wire and cable systems. Plastics Compounding, 11, 26-34 (1988).

[12] Marosi G., Anna P., Bertalan G., Szabó S., Ravadits I., Papp J.: Role of interface modification in flameretarded multiphase polyolefin systems. in 'Fire and polymers' (eds.: Nelson G., Wilkie C.) ACS Symposium Series, Washington, 161-171 (2001).

[13] Keszei S., Matkó S., Bertalan G., Anna P., Marosi G., Tóth A.: Progress in interface modifications: From compatibilization to adaptive and smart interphases. European Polymer Journal, 41, 697-705 (2005).

DOI: $\underline{10.1016 / j . e u r p o l y m j .2004 .10 .039}$

[14] Marosfói B. B., Marosi G. J., Szép A., Anna P., Keszei S., Nagy B. J., Martvonova H., Sajó I. E.: Complex activity of clay and CNT particles in flame retarded EVA copolymer. Polymers for Advanced Technologies, 17, 255-262 (2006).

DOI: $10.1002 /$ pat.691

[15] Szép A., Szabó A., Tóth N., Anna P., Marosi G.: Role of montmorillonite in flame retardancy of ethylene vinyl acetate copolymer. Polymer Degradation and Stability, 91, 593-599 (2006).

DOI: 10.1016/j.polymdegradstab.2005.02.026

[16] McNeill I. C., Ahmed S., Memetea L.: Thermal degradation of vinyl acetate-methacrylic acid copolymer and homopolymers. I. An FTIR spectroscopic investigation of structural changes in the degrading material. Polymer Degradation Stability, 47, 423-433 (1995). DOI: 10.1016/0141-3910(95)00001-1

[17] Holland B. J., Hay J. N.: The thermal degradation of poly(vinyl acetate) measured by thermal analysisFourier transform infrared spectroscopy. Polymer, 43, 2207-2211 (2002).

DOI: 10.1016/S0032-3861(02)00038-1

[18] Clerc L., Ferry L., Leroy E., Lopez-Cuesta J-M.: Influence of talc physical properties on the fire retarding behaviour of (ethylene-vinyl acetate copolymer/ magnesium hydroxide/talc) composites. Polymer Degradation and Stability, 88, 504-511 (2005).

DOI: 10.1016/j.polymdegradstab.2004.12.010

[19] Yu J. C., Xu A., Zhang L., Song R., Wu L.: Synthesis and characterization of porous magnesium hydroxide and oxide nanoplates. Journal of Physical Chemistry B, 108, 64-70 (2004). DOI: $10.1021 / \mathrm{jp} 035340 \mathrm{w}$

[20] Braun U., Schartel B.: Flame retardant mechanisms of red phosphorus and magnesium hydroxide in high impact polystyrene. Macromolecular Chemistry and Physics, 205, 2185-2196 (2004).

DOI: $\underline{10.1002 / \mathrm{macp} .200400255}$
[21] Huang H., Tian M., Liu L., He Z., Chen Z., Zhang L.: Effects of silicon additive as synergists of $\mathrm{Mg}(\mathrm{OH})_{2}$ on the flammability of ethylene vinyl acetate copolymer. Journal of Applied Polymer Science, 99, 3203 3209 (2006).

DOI: 10.1002/app.22494

[22] Montezin F., Lopez Cuesta J-M., Crespy A., Georlette P.: Flame retardant and mechanical properties of a copolymer PP/PE containing brominated compounds/antimony trioxide blends and magnesium hydroxide or talc. Fire and Materials, 21, 245-252 (1997).

DOI: 10.1002/(SICI)1099-1018(199711/12)21:6<245:: AID-FAM616>3.0.CO;2-F

[23] Sivalingam G., Madras G.: Thermal degradation of ternary blends of poly( $\varepsilon$-caprolactone)/poly(vinyl acetate)/poly(vinyl chloride). Journal of Applied Polymer Science, 93, 1378-1383 (2004).

DOI: $10.1002 / a p p .20587$

[24] Shen K. K.: Zinc borates: 30 years of successful development as multifunctional fire retardants. in 'Fire and polymers' (eds.: Nelson G. L. and Wilkie C. A.) American Chemical Society, Washington, 18, 228-239 (2001).

DOI: 10.1021/bk-2001-0797.ch018

[25] Carpentier F., Bourbigot S., Le Bras M., Delobel R., Foulon M.: Charring of fire retarded ethylene-vinyl acetate copolymer-magnesium hydroxide/zinc borate formulations. Polymer Degradation and Stability, 69, 83-92 (2000). DOI: $10.1016 / \mathrm{S} 0141-3910(00) 00044-6$

[26] Genovese A., Shanks R. A.: Structural and thermal interpretation of the synergy and interactions between the fire retardants magnesium hydroxide and zinc borate. Polymer Degradation and Stability, 92, 2-13 (2007).

DOI: 10.1016/j.polymdegradstab.2006.10.006

[27] Durin-Frances A., Ferry L., Cuesta J. M. L., Crespy A.: Magnesium hydroxide/zinc borate/talc compositions as flame-retardants in EVA copolymer. Polymer International, 49, 1101-1105 (2000). DOI: $10.1002 / 1097-0126(200010) 49: 10<1101::$ AIDPI523>3.0.CO;2-5

[28] Karthikeyan B., Mohan S., Baesso M. L.: Spectroscopic and glass transition studies on $\mathrm{Nd}^{3+}$-doped sodium zinc borate glasses. Physica B: Condensed Matter, 337, 249-254 (2003). DOI: $\underline{10.1016 / \mathrm{S} 0921-4526(03) 00411-3}$

[29] Chang J. B., Yan P. X., Yang Q.: Formation of borate zinc $\left(\mathrm{ZnB}_{4} \mathrm{O}_{7}\right)$ nanotubes. Journal of Crystal Growth, 286, 184-187 (2006).

DOI: 10.1016/j.jcrysgro.2005.10.004

[30] Mel'gunov M. S., Fenelonov V. B., Mel'gunova E. A., Bedilo A. F., Klabunde K. J.: Textural changes during topochemical decomposition of nanocrystalline $\mathrm{Mg}(\mathrm{OH})_{2}$ to $\mathrm{MgO}$. Journal of Physical Chemistry B, 107, 2427-2434 (2003). DOI: $10.1021 / \mathrm{jp} 021474 \mathrm{i}$ 
[31] Bourbigot S., Carpentier F., Le Bras M.: Thermal degradation and combustion mechanism of FR EVA. ACS Polymeric Materials: Science and Engineering. Fall Meeting, Washington USA, Vol 83, 68-69 (2000).

[32] García-Martinez J. M., Laguna O., Areso S., Collar E. P.: A dynamic-mechanical study of the role of succinyl-fluorescein grafted atactic polypropylene as interfacial modifier in polypropylene/talc composites. Effect of grafting degree. European Polymer Journal, 38, 1583-1589 (2002).

DOI: 10.1016/S0014-3057(02)00051-4

[33] Chiem L. T., Huynh L., Ralston J., Beattie D. A.: An in situ ATR-FTIR study of polyacrylamide adsorption at the talc surface. Journal of Colloid and Interface Science, 297, 54-61 (2006).

DOI: $\underline{10.1016 / j . j c i s .2005 .10 .037}$
[34] Malandrini H., Clauss F., Partyka S., Douillardt J. M.: Interactions between talc particles and water and organic solvents. Journal of Colloid and Interface Science, 194, 183-193 (1997).

DOI: $10.1006 /$ jcis. 1997.5103

[35] Sain M., Park S. H., Suhara F., Law S.: Flame retardant and mechanical properties of natural fibre-PP composites containing magnesium hydroxide. Polymer Degradation and Stability, 83, 363-367 (2004). DOI: $10.1016 / \mathrm{S} 0141-3910(03) 00280-5$

[36] Alexander G., Cheng Y-B., Burford R. P., Shanks R. A., Mansouri J., Barber K. W., Rodrigo P. D. D., Preston C. M. L.: Ceramifying composition for fire protection. World Patent, WO 2005/095545 (2005). 